\title{
MAPKAP1 wt Allele
}

National Cancer Institute

\section{Source}

National Cancer Institute. MAPKAP1 wt Allele. NCI Thesaurus. Code C105118.

Human MAPKAP1 wild-type allele is located in the vicinity of 9q34.3 and is approximately $270 \mathrm{~kb}$ in length. This allele, which encodes target of rapamycin complex 2 subunit MAPKAP1 protein, plays a role in the regulation of cell growth and survival. 